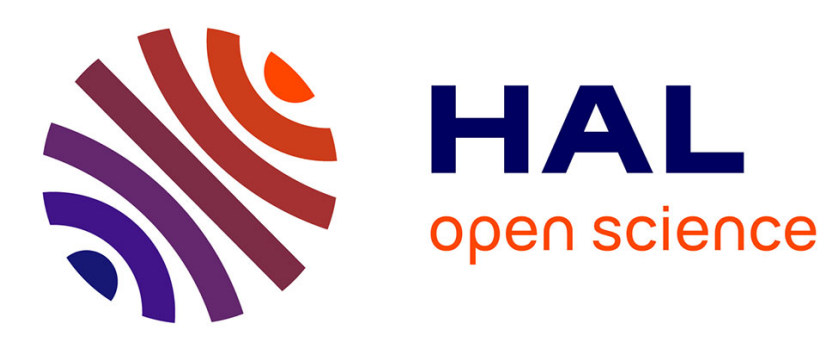

\title{
Effects of stand density on ecosystem properties of subalpine forests in the southern Rocky Mountains, USA
}

Sharon J. Hall, Peter J. Marchand

\section{To cite this version:}

Sharon J. Hall, Peter J. Marchand. Effects of stand density on ecosystem properties of subalpine forests in the southern Rocky Mountains, USA. Annals of Forest Science, 2010, 67 (1), 10.1051/forest/2009083 . hal-00883560

\section{HAL Id: hal-00883560 https://hal.science/hal-00883560}

Submitted on 1 Jan 2010

HAL is a multi-disciplinary open access archive for the deposit and dissemination of scientific research documents, whether they are published or not. The documents may come from teaching and research institutions in France or abroad, or from public or private research centers.
L'archive ouverte pluridisciplinaire HAL, est destinée au dépôt et à la diffusion de documents scientifiques de niveau recherche, publiés ou non, émanant des établissements d'enseignement et de recherche français ou étrangers, des laboratoires publics ou privés. 


\title{
Effects of stand density on ecosystem properties of subalpine forests in the southern Rocky Mountains, USA
}

\author{
Sharon J. HALL ${ }^{1 *}$, Peter J. MARCHAND ${ }^{2}$ \\ ${ }^{1}$ Arizona State University, School of Life Sciences, PO Box 874501, Tempe 85287-4501, AZ, USA \\ ${ }^{2}$ Catamount Center for Geography of the Southern Rockies, 3168 County Road 28, Woodland Park, CO 80863, USA
}

(Received 11 March 2009; accepted 14 August 2009)

Keywords:

foliar chemistry /

phenolic /

soil nitrogen cycling /

stand density /

biogeochemistry

\author{
Mots-clés : \\ chimie foliaire / \\ composés phénoliques / \\ cycle de l'azote du sol / \\ densité du peuplement / \\ biogéochimie
}

\begin{abstract}
- Mixed coniferous, subalpine forest communities in the Rocky Mountains are historically dense and have experienced infrequent, high-severity fire. However, many of these high-elevation stands are thinned for a number of perceived benefits.

- We explored the effects of forest stand density on ecosystem properties in subalpine forests in Colorado, USA, 17-18 y after forests were managed for timber.

- Forest structure significantly altered the composition and chemical signature of plant communities. Previously managed stands contained lower density of overstory trees and higher ground cover compared to paired reference stands. Foliar phenolic concentration of several species was negatively related to basal area of overstory trees. Furthermore, reductions in stand density increased total foliar phenolic:nitrogen ratios in some species, suggesting that gap formation may drive long-term changes in litter quality. Despite significant changes in forest structure, reductions in stand density did not leave a strong legacy in surface soil properties, likely due to the integrity of soil organic matter reserves.

- Changes in forest structure associated with past management has left a long-term impact on plant communities but has only subtly altered soil nutrient cycling, possibly due to trade offs between litter decomposability and microclimate associated with reductions in canopy cover.
\end{abstract}

Résumé - Effets de la densité du peuplement sur les propriétés des écosystèmes des forêts subalpines dans le sud des Montagnes Rocheuses aux USA.

- Les communautés subalpines de forêts mixtes de conifères dans les Montagnes Rocheuses sont historiquement denses et ont peu connu de feux très sévères. Cependant, beaucoup de ces peuplements de haute altitude sont éclaircis pour de nombreux profits.

- Nous avons étudié les effets de la densité des peuplements forestiers sur les propriétés des écosystèmes dans les forêts subalpines du Colorado (USA), 17-18 ans après que les forêts aient été exploitées pour le bois.

- La structure de la forêt a considérablement modifié la composition et la signature chimique des communautés végétales. Auparavant les peuplements exploités renfermaient une plus faible densité d'arbres de l'étage dominant et une couverture du sol plus importante par rapport aux peuplements de référence correspondants. La concentration des composés phénoliques foliaires de plusieurs espèces a été liée négativement à la surface terrière des arbres dominants. En outre, les réductions de la densité du peuplement ont augmenté les rapports composés phénoliques foliaires totaux : azote chez certaines espèces, ce qui suggère que la formation de trouée peut conduire à des changements à long terme de la qualité de la litière. Malgré d'importants changements dans la structure forestière, la réduction de la densité du peuplement n'a pas laissé un héritage solide dans les propriétés de surface du sol, probablement à cause de l'intégrité des réserves de matière organique du sol.

- Les changements dans la structure de la forêt associés à la gestion passée ont laissé un impact à long terme sur les communautés végétales, mais n'ont que discrètement modifié le cycle des nutriments du sol, peut-être à cause des échanges entre les possibilités de décomposition de la litière et le microclimat associé à des réductions du couvert forestier.

\footnotetext{
*Corresponding author: sharonjhall@asu.edu
} 


\section{INTRODUCTION}

Natural, mature forested landscapes are mosaics of spatially uneven and temporally heterogeneous patches shaped by abiotic and biotic processes (Bormann and Likens, 1979). Humans have altered forest landscapes over millennia, primarily through resource extraction and manipulation of fire (Heckenberger et al., 2003). For example, large-scale clearcutting techniques and a century of fire suppression in the USA have homogenized landscape structure and functioning by removing patch-scale events (Fuller et al., 1998; Vellend et al., 2007). While the creation of even-aged stands may have economic benefits in the short-term (Gilless and Buongiorno, 2003), high stand densities and drought have increased the incidence of crown fire and insect outbreaks while also causing decline of native species (McCullough et al., 1998; National Research Council, 2000; Veblen et al., 2000). As a result, forest managers are now seeking alternative harvesting strategies such as thinning and uneven-aged stand management to maximize non-market values and other beneficial ecosystem services (Franklin et al., 1985). Thinning causes changes in stand density, which could alter resource availability and ecological dynamics of remaining plants and microorganisms within forest soils.

Several decades of research have focused on the ecological impacts of harvesting on forest ecosystems, prompted in part by concerns in the late 1960's about the sustainability of clear-cutting and fueled recently by regional and controversial national forest management policies (e.g. 1994 Northwest Forest Plan; Healthy Forest Restoration Act of 2003); (Connaugh, 1970; Ranger et al., 2008). In particular, many studies have explored the short-term consequences of various thinning strategies for ecosystem structure and functioning, including stand productivity and biodiversity. While results vary considerably between ecosystem types, most findings suggest that reducing overstory biomass though selective harvest rapidly increases the complexity of plant communities by encouraging understory growth within the first several years (Covington et al., 1997). Furthermore, changes in habitat structure and species composition, especially when debris is left on site, often leads to increased abundance and diversity of breeding bird and small mammal communities (Converse et al., 2006; Hagar et al., 2004) and may increase arthropod diversity or species composition (Apigian et al., 2006).

The consequences of reduction in stand density for biogeochemical cycling, however, are less clear. Selective harvesting of overstory trees alters microclimatic conditions at the soil surface, often increasing soil temperatures, and thus can change microbial communities, speed decomposition, and increase nutrient cycling and losses in the short-term when plant uptake is reduced (Kaye and Hart, 1998). However, some studies suggest these effects are subtle or absent after the harvesting event (Dannenmann et al., 2007; Feller et al., 2000; Ganjegunte et al., 2004; Gundale et al., 2005, 2006), and others show they are transient (Dannenmann et al., 2006). Results also vary in the long-term as some ecosystems support altered rates of microbial activity and soil properties for years following thinning (Boyle et al., 2005; Grady and Hart, 2006;
Jonard et al., 2006; Maassen et al., 2006), while other ecosystems show few long-term differences from reference conditions (Gundersen et al., 2006).

While some variability between studies is likely due to harvest methods, direct effects of forest management may be less important to ecosystem biogeochemistry than indirect effects through long-term changes in plant communities that vary across ecosystems and management practices (Hart et al., 2005). Nutrient turnover is modulated by microclimate as canopies are opened, but rates of decomposition and nutrient availability are largely driven by carbon supply to microorganisms through litter quantity and quality. Thinning can impact litter quality through changes in species composition, and the extent of post-thinning species modification and persistence may explain different biogeochemical outcomes of forest management (Grady and Hart, 2006). Although less explored, reductions of overstory cover or composition may also affect litter quality through changes in the chemistry of remaining plants and species assemblages (Forkner and Marquis, 2004). Many plant secondary metabolites are responsive to environmental changes and play key roles in nutrient return and herbivory (Hattenschwiler and Vitousek, 2000; Müller et al., 2006). For example, plant-derived polyphenolic compounds can regulate soil nutrient cycling through their variable function as stimulators or inhibitors of microbial growth, and through their ability to mobilize or bind nutrients by complexing with proteins and minerals (Hattenschwiler and Vitousek, 2000). However, few studies have explored the dynamics of phenolic compounds or their impacts to biogeochemical cycling in managed forest ecosystems (Forkner and Marquis, 2004; Hart et al., 2005).

Forest thinning has become a regular practice as a fuel reduction strategy throughout the United States in landscapes that have a history of fire suppression, but due to recent changes in policy and perceptions, it has also become commonplace in ecosystems that historically are not prone to fire and naturally support dense plant communities (Schoennagel et al., 2004). For example, prior to significant human influence, the mixed-coniferous subalpine forests of the Rocky Mountains experienced relatively infrequent (up to many centuries), high-intensity fires (Schoennagel et al., 2004; Sibold et al., 2006). However, selective logging in subalpine forests is currently widespread, in part to reduce perceived fire hazard, but also to control outbreaks of forest pathogens and support other desirable attributes, such as growth of aspen ( $P$. tremuloides; Colorado Division of Forestry, 2005). Furthermore, the impacts of stand density on ecological processes, including insect outbreaks, are not well understood for high elevation ecosystems (Fettig et al., 2007). While many processes are likely to operate similarly to lower elevation, fire-adapted forests, variations in species composition and abiotic factors such as climate, length of growing season, and phenology may lead to significant differences in ecological outcomes (e.g., Griffin and Mills, 2007).

In this study, we assessed the effects of forest stand density on plant community composition and ecosystem properties in high elevation mixed-coniferous, subalpine forests in Colorado. During 2002 and 2003, we measured forest structure 
Table I. Characteristics of overstory vegetation in experimental plots in the mixed-coniferous, subalpine forest at the Catamount Center for Geography of the Southern Rockies (CCGSR).

\begin{tabular}{|c|c|c|c|c|c|c|}
\hline Plot No. & Treatment & Slope $\left({ }^{\circ}\right)$ & Aspect $\left(^{\circ}\right)$ & $\begin{array}{l}\text { Basal area }\left(\mathrm{m}^{2} / \mathrm{ha}\right) \\
\text { All species }>2.5 \mathrm{~cm}\end{array}$ & $\begin{array}{c}\text { \# Stems } \\
>2.5 \mathrm{~cm} \mathrm{dbh} / \mathrm{ha}\end{array}$ & $\begin{array}{c}\text { Canopy } \\
\text { cover }(\%)\end{array}$ \\
\hline 1 & Reference & 30 & 30 & 30.6 & 1201 & 78.4 \\
\hline 1 & Low-density & 23 & 30 & 23.0 & 792 & 73.1 \\
\hline$\overline{2}$ & Reference & 38 & 342 & 39.0 & 1619 & 85.4 \\
\hline 2 & Low-density & 35 & 352 & 20.4 & 832 & 63.4 \\
\hline 3 & Reference & 22 & 320 & 36.2 & 1924 & 81.6 \\
\hline 3 & Low-density & 25 & 296 & 31.0 & 1276 & 80.4 \\
\hline$\overline{4}$ & Reference & 9 & 2 & 38.8 & 1284 & 87.8 \\
\hline 4 & Low-density & 2 & 12 & 26.0 & 838 & 69.1 \\
\hline 5 & Reference & 34 & 354 & 46.1 & 1604 & 87.4 \\
\hline \multirow[t]{2}{*}{5} & Low-density & 28 & 26 & 21.7 & 788 & 74.9 \\
\hline & $p *$ & & & 0.02 & 0.01 & 0.04 \\
\hline
\end{tabular}

$* p$-value calculated from paired $t$-test by treatment; $n=5$.

and chemistry and soil nutrient cycling using a retrospective approach by comparing plots that had been managed 17-18 y ago (low-density) with paired plots that had not been managed (reference). We also used a regression approach to explore the importance of forest structure (basal area, stem density, canopy cover) on ecosystem properties across all sites. We expected ecological processes in the subalpine to follow patterns anticipated for post-management coniferous forests at lowerelevations, including increased understory plant cover. We also expected that rates of nitrogen cycling would be faster in low density plots due to changes in microclimate (higher temperatures leading to higher rates of decomposition), and that nutrient enrichment would be significantly and positively related to foliar tissue quality.

\section{METHODS}

\subsection{Site description}

We explored the effects of forest structure on ecosystem properties in subalpine forests within the privately-held Catamount Center for Geography of the Southern Rockies (CCGSR), an 81-ha research center located between 2700-3000 m in elevation on the north slope of Pikes Peak, Colorado (Fig. 1). Mean annual temperature at the CCGSR is $2.6{ }^{\circ} \mathrm{C}$, ranging from $-6.3{ }^{\circ} \mathrm{C}$ in January to $13.3{ }^{\circ} \mathrm{C}$ in July (Ruxton Park Climate Data, Western Regional Climate Center, 2007). Mean annual precipitation is $602 \mathrm{~mm}, 43 \%$ of which falls during June, July, and August. Forests of the CCGSR are underlain by Pikes Peak granite, the dominant geological feature of the region. Soils are shallow, gravelly, coarse sandy loams of the Catamount-Guffey complex, classified as Ustic Dystrocryepts and Ustic Haplocryalfs (Carpenter et al., 1998; NRCS, 2006).

Selective logging occurred on CCGSR lands during 1983-84 as prescribed by state forest service personnel for general forest stand improvement purposes without clear statement of goals such as target densities, age distributions, or stand composition. Tree stump diameters are generally small and removal targets were specified in cords, indicating small tree removal for a firewood sale rather than commercial timber sale. Approximately half of the overstory trees on each of several small tracts (ca 2-5 ha) were removed using hand methods with trees bucked for fuel-wood sales and slash treated by lop-andscatter.

We combined a retrospective experimental design with a regression approach in order to analyze the impacts of overstory stand density on ecological properties of these high elevation forests. Retrospective designs are common in the literature and represent a powerful method to assess long-term impacts beyond the time scale of many field experiments (Grady and Hart, 2006; Powers, 1989). However, they are also inherently limited because treatments are not randomly assigned and often initial conditions or harvest methods are unknown. To minimize problems associated with a retrospective approach, we used stereo pairs of air photos and ground measurements to identify 10 plots that we paired according to the following six criteria (low-density and reference stands, $n=5$, Fig. 1 and Tab. I): (a) evidence of previous harvesting (stumps), (b) slope $\left(\leq 7^{\circ}\right.$ difference between pairs), (c) aspect ( $\leq 35^{\circ}$ difference between pairs), (d) elevation $(2930 \pm 15 \mathrm{~m}$ ), (e) stand density (reference sites $\geq 30 \%$ higher stems/ha than low-density sites), and (e) species composition (similar representation of dominant tree species in the overstory). Overstory vegetation in the plots included Engelmann spruce (Picea engelmannii Parry ex Engelm.), Douglas-fir (Pseudotsuga menziesii (Mirb.) Franco), limber pine (Pinus flexilis James) and trembling aspen (Populus tremuloides Michx). Some 30 species of vascular plants were found in the understory, varying among sites, with three woody species common to all plots: Common juniper (Juniperus communis L.), kinnikinnick (Arctostaphylos uva-ursi (L.) Spreng), and Wood's rose (Rosa woodsii Lindl.). Several species of terricolous lichens were also present, including the nitrogen-fixing genus, Peltigera spp. Few exotic species were present within the study area.

\subsection{Forest structure}

In each plot, we determined the composition and structure of overstory tree species and ground cover of understory plant communities across a $\sim 0.5$ ha grid (composed of $49,10 \mathrm{~m} \times 10 \mathrm{~m}$ grid squares). 
Within this grid, we counted, identified, and measured diameters of all trees $(>2.5 \mathrm{~cm} \mathrm{DBH})$ and saplings $(<2.5 \mathrm{~cm} \mathrm{DBH}$ and $>1 \mathrm{~m}$ in height) of overstory species. At alternate grid intersections (i.e. every $20 \mathrm{~m}$ ), we measured canopy cover with a concave spherical densiometer (Jennings et al., 1999). We obtained four closure measurements at each intersection, facing each cardinal direction, and we averaged these results to determine canopy closure for that point. A within-plot average of 9 such point measurements (i.e. $9 \times 4$ densiometer readings) was used for the overall canopy closure for each plot. To determine composition of understory vegetation, we placed a $0.25 \mathrm{~m}^{2}$ raised quadrat grid on the forest floor at each $10 \mathrm{~m}$ intersection of the grid and identified the type of groundcover present at each point in the quadrat (quadrat raised by four wooden legs, area divided into 64 squares, 49 observations/quadrat). Woody understory plants were identified by species (J. communis, A. uva-ursi, $R$. woodsii), while cover of coarse woody debris, moss, herbaceous vegetation, and lichen (Peltigera or "Other") were grouped. Lichens of the Peltigera genus were identified separately from other terricolous lichens due to their potential to affect nitrogen inputs through nitrogen-fixation (Knowles et al., 2006). We calculated percent cover of each cover type/species by dividing the number of observations per cover type by the total number of quadrat points (49).

\subsection{Foliar carbon $(\mathrm{C})$, nitrogen $(\mathrm{N})$, and total phenolics}

During late September, 2003, we sampled mature, current year foliage from four individuals per plot of seven different species of plants and lichen that were common to all plots. For overstory species (P. engelmannii, P. flexilis, P. menzeisii), we collected and composited four subsamples per individual, two from intact branches within arms reach and two from mid-level branches using a shotgun. Four subsamples of mature, current-year leaves were also taken and composited from four individuals per plot of other species (J. communis, $R$. woodsii, A. uva-ursi, and Peltigera lichen). To measure total phenolic content of foliage, we used the Folin-Denis method described in Hattenschwiler et al. (2003). In brief, phenolic compounds were extracted by shaking $30 \mathrm{mg}$ of air-dried, finely ground plant material in 50\% ethanol every $15 \mathrm{~min}$ for $2 \mathrm{~h}$ and allowing the extract to settle overnight. Within $24 \mathrm{~h}$, we added $200 \mathrm{uL}$ of the supernatant to a $50 \mathrm{~mL}$ flask containing $25 \mathrm{~mL}$ deionized water and $2.5 \mathrm{~mL}$ of Folin-Denis reagent. After $3 \mathrm{~min}$, we added $5 \mathrm{~mL}$ saturated sodium carbonate and brought the total solution to $50 \mathrm{~mL}$ with deionized water. At $20 \mathrm{~min}$, we measured the sample for absorbance at $760 \mathrm{~nm}$. We used three concentrations of tannic acid as a standard. Plant tissue was also dried at $70{ }^{\circ} \mathrm{C}$ in paper coin envelopes, ground to a fine powder on a ball mill, wrapped, and analyzed in triplicate for total $\mathrm{C}$ and N on a NC2100 Combustion Analyzer (CE Elantech, Lakewood, NJ) using certified standards.

\subsection{Soil properties and processes}

Surface soils were collected from each plot during two seasons in 2003, in mid-summer (July) and again in early winter before significant snow cover (November). Three soil samples composed of three cores each $(15 \mathrm{~cm}$ depth) were taken from random locations across each plot and stored in coolers (approx. $10^{\circ} \mathrm{C}$ ) until processing. All soils were sieved to $2 \mathrm{~mm}$ and processed within $48 \mathrm{~h}$ of collection. Total C and N were measured (summer only) on an NC2100 Combustion Analyzer after drying at $70{ }^{\circ} \mathrm{C}$ and grinding with a ball mill.
Organic matter was measured (winter only) by mass loss after combustion for $2 \mathrm{~h}$ at $550{ }^{\circ} \mathrm{C}$ (Nelson, 1994). During both seasons, one $10 \mathrm{~g}$ subsample from each sample was immediately shaken for $1 \mathrm{~min}$ in $50 \mathrm{~mL} 2 \mathrm{~N} \mathrm{KCl}$, set aside for 18-36 h, filtered through pre-leached Whatman \#42 filters, and then frozen for later analysis for extractable ammonium $\left(\mathrm{NH}_{4}^{+}-\mathrm{N}\right)$ and nitrite + nitrate (hereafter referred to as $\mathrm{NO}_{3}^{-}-\mathrm{N}$, as nitrite pools were assumed to be minimal). Another $10 \mathrm{~g}$ subsample was placed in a small, capped cup and incubated in the lab at $22{ }^{\circ} \mathrm{C}$ for $7 \mathrm{~d}$. After the incubation, soils were extracted as described above. All $\mathrm{KCl}$ extracts were analyzed colorimetrically for $\mathrm{NH}_{4}^{+}-\mathrm{N}$ and $\mathrm{NO}_{3}^{-}-\mathrm{N}$ using a Lachat Quikchem 8000 autoanalyzer (Hach Company, Loveland, $\mathrm{CO}$ ). Net $\mathrm{N}$ mineralization was calculated as the difference between the sum of $\mathrm{NH}_{4}^{+}$and $\mathrm{NO}_{3}^{-}$concentrations before and after each incubation. Net nitrification was calculated as the difference between $\mathrm{NO}_{3}^{-}$concentrations before and after each incubation. Gravimetric soil water was determined during both seasons by drying soil subsamples for $24 \mathrm{~h}$ at $105^{\circ} \mathrm{C}$.

\subsection{Statistical analyses}

All statistical tests were performed using SPSS 11.0 software (SPSS, 2005). Student's paired t-tests were used to test differences between low-density and reference treatments in the paired experimental plots used in this study $(n=5)$. Non-parametric Wilcoxon signed rank analyses were used for data that did not conform to parametric assumptions. Although Bonferroni corrections are often employed when analyzing multiple variables within a system, use of this statistical test in ecological studies is controversial (Moran, 2003). Rather, we report statistical significance at $p \leq 0.05$ and interpret our results in the context of what is likely to be ecologically, rather than simply statistically, significant (Moran, 2003). Least-squares regression analyses and Pearson's coefficients of correlation $(r)$ were used to determine significant relationships between continuous variables. In particular, we tested the relationship between our response variables and measures of forest structure, including stem density (stems $>2.5 \mathrm{~cm}$ $\mathrm{dbh} / \mathrm{ha})$, canopy cover (\%), and basal area of overstory trees $\left(\mathrm{m}^{2} / \mathrm{ha}\right)$. In addition, we examined linear relationships between soil properties and processes to explore factors controlling nutrient availability. Variables that were non-normally distributed or heteroscedastic were log-transformed prior to analyses.

\section{RESULTS}

\subsection{Forest structure}

Structure of overstory tree species (defined as $>2.5 \mathrm{~cm} \mathrm{dbh}$ ) was significantly different in low-density compared to reference plots (Tab. I). Low-density plots supported $14-53 \%$ lower basal area, 34-51\% lower stem density, and $7-26 \%$ lower canopy cover compared to their reference pairs. Differences were due primarily to reductions in P. engelmanii and P. menzeisii that were likely selectively removed from the site during management (Tab. II). Furthermore, density of saplings, including $P$. tremuloides, was not significantly related to total overstory basal area, stem density, or canopy cover.

The structure of understory vegetation was also significantly affected $\sim 20$ y after forest management. Low-density 
Table II. Number of stems by size class and species in five, paired experimental plots.

\begin{tabular}{|c|c|c|c|c|c|c|}
\hline \multirow[b]{2}{*}{ Size class } & \multirow[b]{2}{*}{ Species } & \multicolumn{2}{|c|}{ Reference } & \multicolumn{2}{|c|}{ Low-density } & \multirow[b]{2}{*}{$p *$} \\
\hline & & Mean & SE & Mean & $\mathrm{SE}$ & \\
\hline \multirow[t]{5}{*}{ All trees } & P. engelmanii & 823.8 & 115.4 & 403.6 & 89.7 & 0.01 \\
\hline & P. menzeisii & 232.2 & 51.8 & 132.0 & 24.7 & 0.05 \\
\hline & P. flexilis & 234.0 & 40.8 & 242.6 & 95.0 & 0.91 \\
\hline & P. tremuloides & 231.2 & 66.8 & 118.0 & 38.2 & 0.13 \\
\hline & All species & 1521.2 & 130.0 & 896.2 & 92.0 & 0.00 \\
\hline Stems & P. engelmanii & 336.2 & 59.1 & 164.0 & 43.4 & 0.06 \\
\hline \multirow[t]{4}{*}{$2.5-10 \mathrm{~cm} \mathrm{dbh}$} & P. menzeisii & 68.6 & 23.0 & 21.4 & 7.0 & 0.05 \\
\hline & P. flexilis & 98.6 & 20.7 & 107.8 & 30.5 & 0.66 \\
\hline & P. tremuloides & 52.4 & 33.4 & 27.0 & 8.0 & 0.39 \\
\hline & All species & 555.8 & 90.4 & 320.2 & 30.8 & 0.05 \\
\hline Saplings & P. engelmanii & 300.6 & 50.9 & 214.6 & 72.7 & 0.21 \\
\hline \multirow[t]{4}{*}{$<2.5 \mathrm{~cm} \mathrm{dbh}$} & P. menzeisii & 31.0 & 7.5 & 35.6 & 10.2 & 0.74 \\
\hline & P. flexilis & 59.4 & 13.0 & 90.4 & 22.9 & 0.14 \\
\hline & P. tremuloides & 0.8 & 0.8 & 5.2 & 3.3 & 0.18 \\
\hline & All species & 391.8 & 48.1 & 345.8 & 68.7 & 0.56 \\
\hline
\end{tabular}

* Significance value from paired t-tests by species and size class. $P$ values considered significant at $p \leq 0.05$ are represented in bold.

plots supported a higher percent cover of herbaceous vegetation and juniper in the understory compared to reference plots and lower ground cover of moss (Fig. 2; Wilcoxon Signed Rank test, $p=0.04$ for all three plant groups). Cover of $A$. $u v a$ ursi and lichens were unaffected by stand density. Additionally, of the three metrics of overstory structure, stem density was most significantly related to cover of understory vegetation when plotted individually by cover type (Fig. 2). However, basal area was the only metric of stand density that was significantly (and negatively) related to total vegetated ground cover (Linear regression, log (\% vegetated ground cover) $\times$ basal area: $\left.r^{2}=0.45, p=0.03\right)$.

\subsection{Foliar chemistry}

Stand density significantly affected foliar chemistry of vegetation, including nutrient concentrations and elemental stoichiometry of both overstory and understory species. Nitrogen concentrations were significantly lower and $\mathrm{C}: \mathrm{N}$ ratios higher in foliage of $J$. communis, $R$. woodsii, and P. engelmannii in low-density compared to reference plots (Tab. III). Total phenolic content of foliage was also elevated in J. communis and $R$. woodsii within low-density plots by $12 \%$ and $22 \%$, respectively. Furthermore, foliar phenolics in several species surveyed were significantly and negatively related to structure of overstory trees. Of the three metrics of forest structure used, basal area was most strongly related to foliar phenolic content. Basal area was significantly related to foliar phenolic content in three of six species surveyed, including one overstory species (P. flexilis) and two understory species (J. communis and $R$. woodsii, Fig. 3).
Table III. Soil properties and foliar chemistry paired experimental plots.

\begin{tabular}{lcclllll}
\hline & \multicolumn{2}{c}{ Reference } & & \multicolumn{2}{c}{ Low-density } & \\
\cline { 2 - 3 } & Mean & SE & & Mean & SE & $p$ \\
\hline Soil properties & & & & & & \\
Soil organic matter $(\%)$ & 14.55 & 1.08 & & 14.40 & 1.64 & 0.90 \\
Total soil carbon $(\%)$ & 8.42 & 0.74 & & 7.68 & 1.00 & 0.45 \\
Total soil nitrogen $(\%)$ & 0.36 & 0.02 & & 0.31 & 0.03 & 0.14
\end{tabular}

\section{Foliar chemistry}

Total nitrogen (\%)

\begin{tabular}{lccccc} 
A. uva-ursi & 1.25 & 0.02 & 1.18 & 0.03 & 0.18 \\
J. communis & 1.51 & 0.06 & 1.37 & 0.03 & $\boldsymbol{0 . 0 2}$ \\
R. woodsii & 1.76 & 0.11 & 1.45 & 0.13 & $\mathbf{0 . 0 3}$ \\
Peltigera lichen & 4.26 & 0.07 & 4.22 & 0.09 & 0.70 \\
P. engelmannii & 1.44 & 0.04 & 1.37 & 0.06 & $\mathbf{0 . 0 3}$ \\
P. menziesii & 1.26 & 0.02 & 1.26 & 0.01 & 0.91 \\
P. flexilis & 1.24 & 0.03 & 1.17 & 0.03 & 0.16 \\
Total carbon:nitrogen & & & & & \\
A. uva-ursi & 42.11 & 0.75 & 44.89 & 0.94 & 0.14 \\
J. communis & 34.05 & 1.40 & 38.15 & 1.09 & $\mathbf{0 . 0 1}$ \\
R. woodsii & 26.49 & 2.06 & 32.43 & 3.19 & $\mathbf{0 . 0 4}$ \\
Peltigera lichen & 10.30 & 0.18 & 10.39 & 0.19 & 0.76 \\
P. engelmannii & 34.91 & 1.05 & 37.32 & 1.51 & $\mathbf{0 . 0 2}$ \\
P. menziesii & 40.60 & 0.66 & 40.51 & 0.26 & 0.87 \\
P. flexilis & 41.25 & 1.13 & 43.49 & 0.95 & 0.18 \\
Polyphenols (\% dry & & & & & \\
A. uva-ursi & 22.71 & 1.12 & 21.59 & 0.80 & 0.44 \\
J. communis & 8.60 & 0.39 & 9.63 & 0.24 & $<\boldsymbol{0 . 0 1}$ \\
R. woodsii & 16.06 & 0.72 & 19.49 & 0.64 & $<\boldsymbol{0 . 0 1}$ \\
P. engelmannii & 7.56 & 0.17 & 7.80 & 0.32 & 0.63 \\
P. menziesii & 6.28 & 0.21 & 6.19 & 0.19 & 0.85 \\
P. flexilis & 7.03 & 0.58 & 7.94 & 0.31 & 0.14 \\
\hline & & & & & \\
\hline
\end{tabular}

Stand density was also significantly related to relationships between foliar compounds, which are often used as indices of ecosystem processes such as decomposition (Tab. III and Fig. 4; Aber and Melillo, 1980). Foliar C:N ratios were significantly correlated to foliar phenolic content in J. соттиnis (Pearson's correlation, $r=0.54, p=0.01$ ), P. flexilis $(r=0.74, p<0.01)$, and $R$. woodsii $(r=0.85, p<0.01)$, but not in A. uva-ursi, P. engelmannii, or P. menzeisii. As with the other ecosystem variables measured, basal area of overstory trees best predicted the ratio of total phenolics to foliar N. Basal area was significantly and negatively related to total foliar phenolics: $\mathrm{N}$ in three of six species surveyed, including R. woodsii, J. communis, and P. flexilis (Fig. 4).

\subsection{Soil properties and processes}

Despite clear changes in vegetation structure and chemistry, stand density had only subtle effects on soil properties 


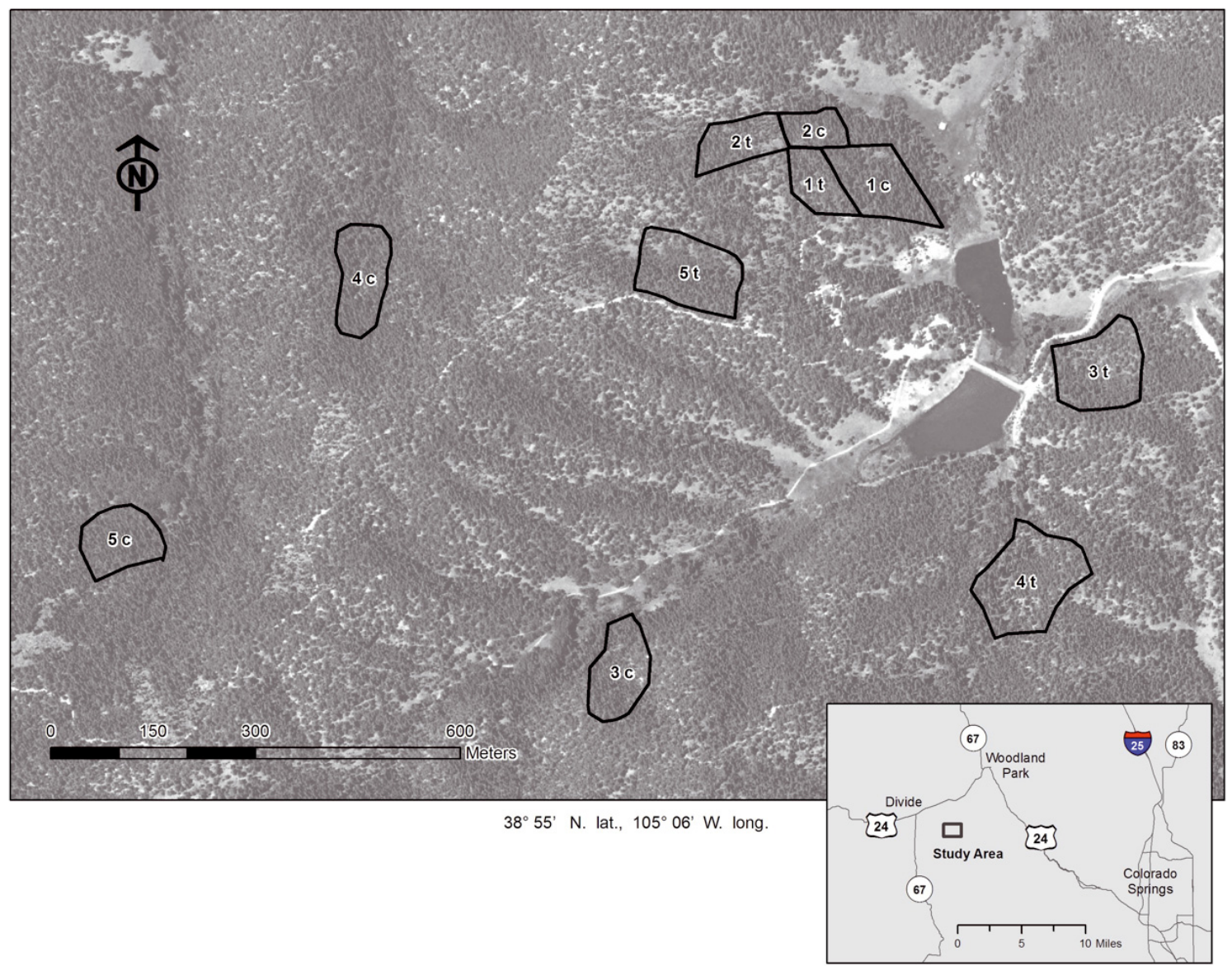

Figure 1. Location of experimental plots at the Catamount Center for Geography of the Southern Rockies (CCGSR) in southern Colorado, USA. Paired experimental plots are labeled 1-5, c (control; reference plot) and t (thinned; low-density plot). Pairs were chosen to be similar with respect slope, aspect, elevation, stand density, and species composition (similar representation of dominant tree species in the overstory).

or processes related to $\mathrm{N}$ cycling (Tabs. III and IV). We found no significant effects of former management on organic matter, total soil carbon and nitrogen, gravimetric moisture, nitrate concentrations, or net nitrogen mineralization in the top $15 \mathrm{~cm}$ of soil. Similarly, none of these metrics were significantly correlated with any measure of forest structure (basal area, stem density, or canopy cover). Although not significant at $p \leq 0.05$, pools of soil extractable ammonium (paired t-test by treatment, $p=0.07$ ) and rates of net nitrification (paired t-test by treatment, $p=0.07$ ) were always higher in reference compared to low-density plots in summer. Gravimetric soil moisture (Pearson's correlation, $r=0.47, p=0.04$ ) and ammonium concentrations (Pearson's correlation, $r=0.53 ; p=$ 0.02 ) were significantly and positively correlated to organic matter content in the top $15 \mathrm{~cm}$ of soil, but soil organic matter was not related to forest density or percent vegetated ground cover. Pools of ammonium were significantly larger than nitrate (the latter near or below the detection limit), in all plots in both seasons (paired t-test by season; $p<0.03$; Tab. IV). Although July soils were wetter than those in November in both low-density (paired t-test by season; $p=0.02$ ) and reference plots (paired t-test by season; $p=<0.001$ ), season had
Table IV. Soil nitrogen cycling in paired experimental plots in July, 2003 (summer) and November 2003 (winter).

\begin{tabular}{|c|c|c|c|c|c|c|}
\hline \multirow[b]{2}{*}{ Variable } & \multirow[b]{2}{*}{ Month } & \multicolumn{2}{|c|}{ Reference } & \multicolumn{2}{|c|}{ Low-density } & \multirow[b]{2}{*}{$p$} \\
\hline & & Mean & $\mathrm{SE}$ & Mean & $\mathrm{SE}$ & \\
\hline \multirow{2}{*}{ Soil moisture $(\%)$} & July & 25.31 & 1.30 & 20.02 & 3.18 & 0.21 \\
\hline & Nov & 12.10 & 1.60 & 10.70 & 1.54 & 0.51 \\
\hline \multirow{2}{*}{$\begin{array}{l}\text { Exchangeable } \mathrm{NH}_{4}^{+} \\
\left(\mu \mathrm{g} \mathrm{N} \mathrm{g}^{-1}\right)\end{array}$} & July & 9.09 & 1.48 & 6.43 & 0.86 & 0.07 \\
\hline & Nov & 8.02 & 1.44 & 6.79 & 1.11 & 0.28 \\
\hline \multirow{2}{*}{$\begin{array}{l}\text { Exchangeable } \mathrm{NO}_{3}^{-} \\
\left(\mu \mathrm{g} \mathrm{N} \mathrm{g}^{-1}\right)\end{array}$} & July & 0.11 & 0.11 & 0.04 & 0.04 & 0.61 \\
\hline & Nov & 0.01 & 0.01 & 0.02 & 0.02 & 0.75 \\
\hline \multirow{2}{*}{$\begin{array}{l}\text { Net } \mathrm{N} \text { mineralization } \\
\left(\mu \mathrm{g} \mathrm{N} \mathrm{g}^{-1} \mathrm{~d}^{-1}\right)\end{array}$} & July & 0.19 & 0.09 & 0.24 & 0.11 & 0.35 \\
\hline & Nov & -0.06 & 0.03 & 0.00 & 0.03 & 0.22 \\
\hline \multirow{2}{*}{$\begin{array}{l}\text { Net nitrification } \\
\left(\mu \mathrm{g} \mathrm{N} \mathrm{g}^{-1} \mathrm{~d}^{-1}\right)\end{array}$} & July & 0.07 & 0.05 & 0.02 & 0.02 & 0.10 \\
\hline & Nov & 0.00 & 0.00 & 0.00 & 0.00 & 0.36 \\
\hline
\end{tabular}

$\mathrm{NH}_{4}^{+}=$ammonium ion; $\mathrm{NO}_{3}^{-}=$nitrate ion.

no significant effect on inorganic $\mathrm{N}$ pools or net $\mathrm{N}$ transformations in either treatment. 


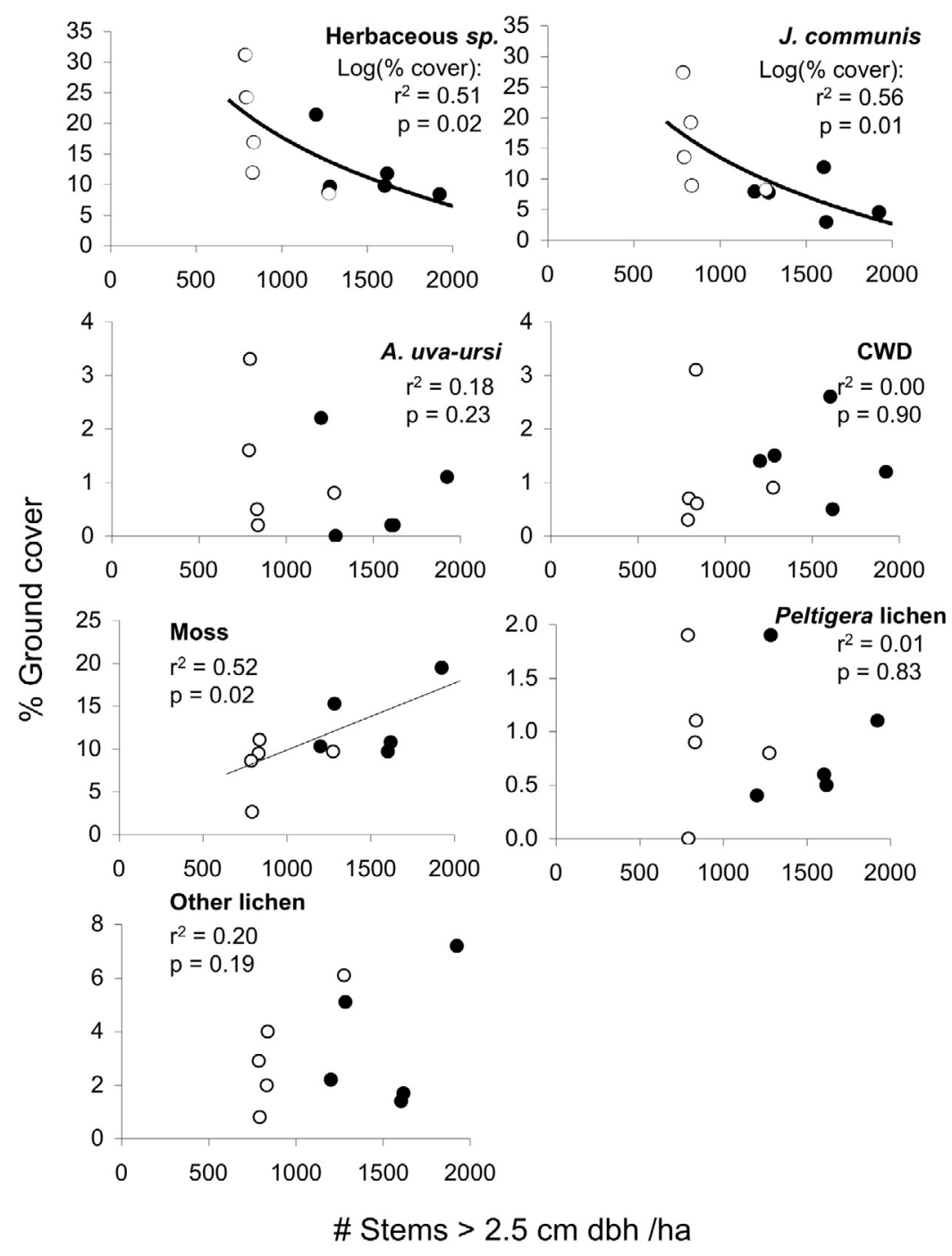

Figure 2. Linear relationships between density of stems (\# stems $>2.5 \mathrm{~cm} \mathrm{dbh/ha)} \mathrm{and} \mathrm{percent} \mathrm{cover} \mathrm{of} \mathrm{understory} \mathrm{vegetation} \mathrm{and} \mathrm{litter} \mathrm{in} \mathrm{the}$ 10 experimental plots at the CCGSR. Low-density and reference plots are represented as open (white) and closed (black) circles, respectively. Statistics are from linear regression analyses (stem density $\times \%$ cover of patch type). CWD $=$ coarse wood debris.

\section{DISCUSSION}

After nearly two decades of regrowth, legacies of former management remain in the structure and chemical composition of the mixed-coniferous, subalpine forest community. Stand density of the overstory was significantly correlated with cover of understory species, leading to increased cover of herbaceous plants and woody shrubs in thinned plots, especially J. communis, a common shrub in Rocky Mountain forests. Changes in plant community structure have also had lasting implications for foliar chemistry.

Because light is often limiting to the growth of understory plant communities in dense, subalpine forests (Lajzerowicz et al., 2004), a decrease in canopy cover due to harvest often stimulates production in the seedling bank, shrubs, and herbaceous species (Lindgren et al., 2006). Furthermore, increased light availability at the soil surface may increase temperatures in the short term, stimulating heterotrophic microbial communities responsible for decomposition and increasing $\mathrm{N}$ availability for understory plants during the time when competition is limited (Titus et al., 2006). Ecosystem simulation models suggest that growth of remaining trees is increased following thinning due to increased stem/leaf ratios and allocation to aboveground vs. belowground biomass (Petritsch et al., 2007). Thus, while high productivity ecosystems can reach canopy closure within years of gap formation (Denslow et al., 1998), it is likely that slow growth rates in these high elevation forests allow canopy gaps to persist in formerly managed stands, thus maintaining higher coverage of understory vegetation.

Although some studies have found that thinning increased the density of young trees in the understory (Zenner et al., 1998), we found no impact of stand density on abundance or composition of saplings/suckers of overstory trees, including the early successional and highly valued species, quaking 

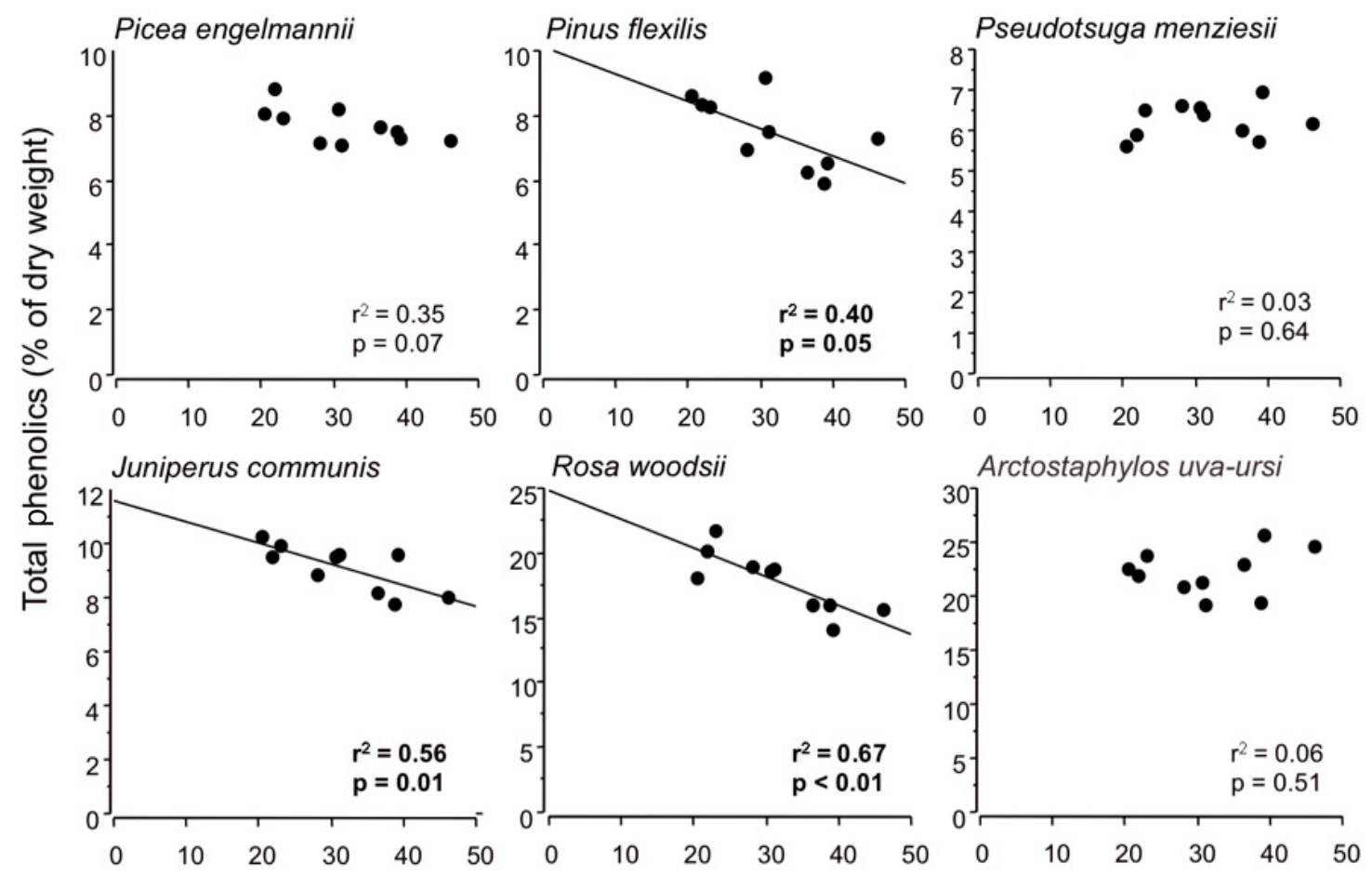

Basal area of overstory trees $\left(\mathrm{m}^{2} / \mathrm{ha}\right)$

Figure 3. Linear relationship between stand density (basal area of overstory trees, $\mathrm{m}^{2} / \mathrm{ha}$ ) and foliar phenolic content (\% dry weight) of six plant species common to all plots. Statistics are from linear regression analyses (basal area $\times$ total phenolic content) by species.

Picea engelmannii

Pinus flexilis

Pseudotsuga menziesii

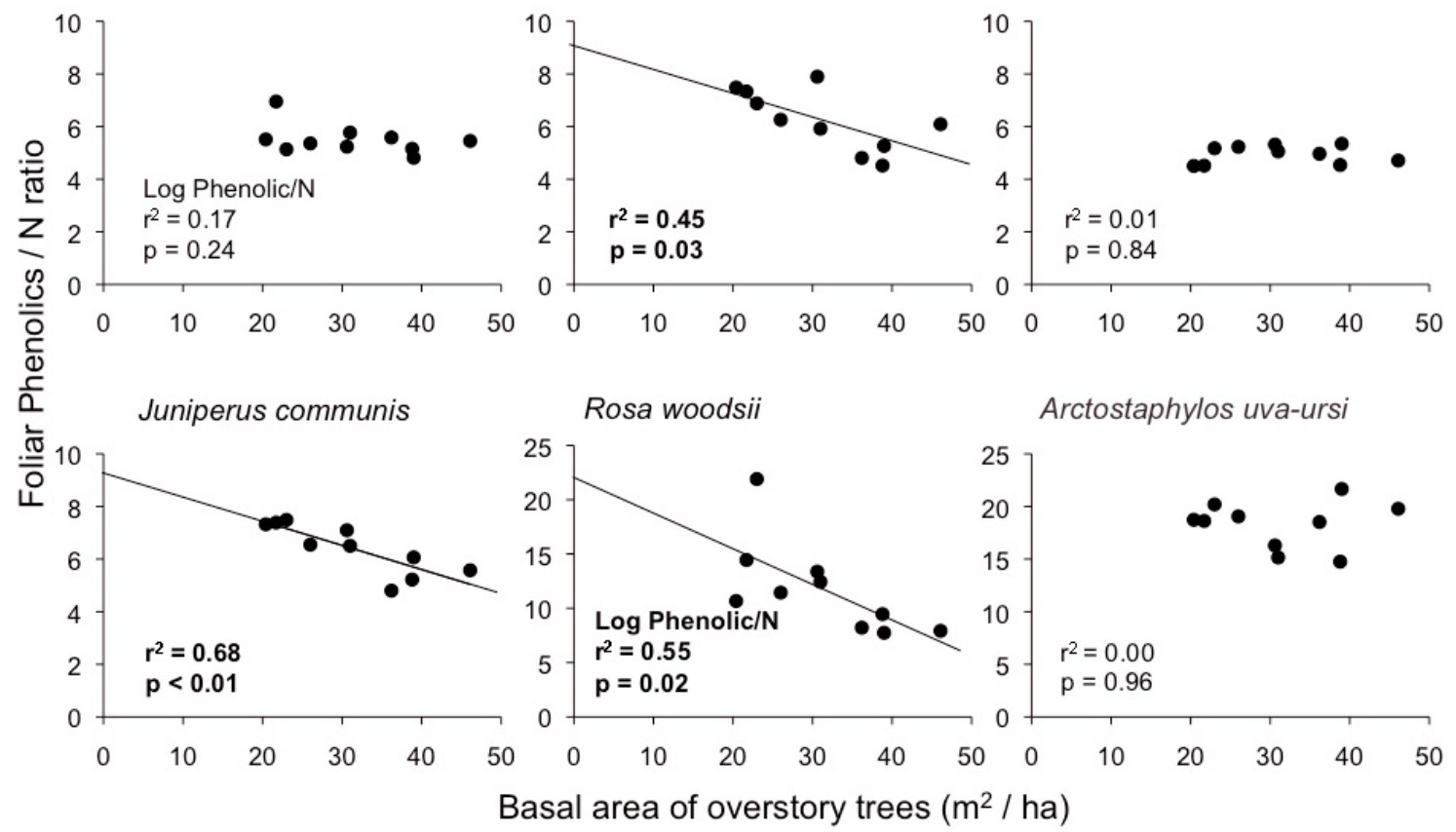

Figure 4. Linear relationship between stand density (basal area of overstory trees, $\mathrm{m}^{2} / \mathrm{ha}$ ) and total foliar phenolic (\% dry weight) / $\mathrm{N}(\%)$ ratio of six plant species common to all plots. Statistics are from linear regression analyses (basal area $\times$ phenolic/N content) by species. $Y$-axis transformed for linear regressions where noted. 
aspen ( $P$. tremuloides). Recent surveys have shown a marked decline in aspen communities across the United States, including 50-95\% loss of stands on the Colorado Plateau and 30\% decline since the 1930s in Wisconsin and Michigan (Bartos, 2000). Because aspen are adapted to disturbance, dense, firesuppressed coniferous forests combined with heavy ungulate browsing have been thought to be responsible for these changes (Colorado Division of Forestry, 2005; Hessl, 2002). Recently, however, research suggests that large scale declines in aspen populations are also highly associated with drought and natural successional processes (Colorado Forest Restoration Institute, 2006; Hogg et al., 2005). Consequently, forest managers have sought to encourage aspen growth through timber harvest combined with ungulate control via hunting and predator reintroduction (Ripple and Beschta, 2007). A sizeable population of elk and mule deer occupy the CCGSR and thus may be responsible for insignificant growth responses to forest density in the aspen sapling community (Carpenter et al., 1998).

While stem density affected plant communities of the CCGSR, it also had consequences for foliar chemistry. We expected that a reduction in overstory density would increase nutritional quality of foliage as competition is alleviated (Wang et al., 2000). However, thinning significantly reduced foliar nitrogen content and increased $\mathrm{C}: \mathrm{N}$ ratios in several overstory and understory species, possibly due to increases in foliar phenolic concentration. Phenolics play diverse roles in plant physiology, as deterrents to herbivory, protection from uv radiation or cold-induced photoinhibition, and signaling compounds, among others (Lindroth and Hwang, 1996; Moore et al., 2004; Weinig et al., 2004). Phenolic compounds can be induced by leaf damage in some species, but they are also controlled by nutrient limitation and physiological tradeoffs between growth, defense, and other factors such as differentiation and reproduction (Jones and Hartley, 1999; Stamp, 2003). Although we did not measure herbivory in our study, preliminary results from a pilot study in our sites suggest that abundance of Lepidoptera is not different between low-density and reference plots (S. Johnson, unpublished data). Furthermore, soil inorganic $\mathrm{N}$ concentrations were not related to foliar phenolic content in any of the species surveyed. Although evidence from managed forest ecosystems is limited, foliar phenolics have been shown to be responsive to environmental factors associated with changes in forest structure, including herbivory and light availability (Chacon and Armesto, 2006; Covelo and Gallardo, 2001; Forkner and Marquis, 2004; Osier and Lindroth, 2006). Increased light availability could lead to production of uv-protective phenolics, particularly when plant growth is limited by nutrients or cold temperatures (Moore et al., 2004). Thus, it is possible that reduction of stand density in this high elevation ecosystem led to phenolic biosynthesis from excess photosynthate relative to growth, leading to possible benefits against uv radiation, frost damage, and herbivory in several of the subalpine plant species found in our study.

Although variability in types of compounds and their possible fates confounds evidence in the literature, high concentrations of phenolics relative to $\mathrm{N}$ in plant litter have been shown to decrease rates of decomposition in soils, thus restricting nu- trient availability to plants and slowing ecosystem nutrient cycling in a positive feedback cycle (Aerts and deCaluwe, 1997; Lorena et al., 2005; Northup et al., 1998). In the subalpine forests studied here, the ratio of total foliar phenolics: $\mathrm{N}$ in fresh leaves was significantly and negatively related to overstory density in three of the six species surveyed, P. flexilis, J. communis, and $R$. woodsii. If the pattern in leaves holds also for litter, reduction in stand density may decrease litter quality, particularly if the foliar phenolic pool is composed of high molecular weight compounds that remain through senescence and resist solubility (Hattenschwiler and Vitousek, 2000).

However, despite changes in foliar chemistry, we did not find strong evidence to suggest that rates of decomposition or nutrient cycling are operating more slowly in low-density compared to reference plots in this forest. Although statistical power was limited by relatively low sample size combined with inherent heterogeneity in soil processes, soil $\mathrm{N}$ concentrations or net rates of $\mathrm{N}$ mineralization during July and November were not significantly related to any measure of forest density. If reduction in stand density negatively affects litter quality of prominent overstory and understory species, other factors may be operating to counteract this effect such that decomposition rates remain similar to reference stands. Changes in species composition with selective harvest could feed back to speed decomposition depending on litter quality and quality of remaining vegetation (Forkner and Marquis, 2004; Grady and Hart, 2006). Low-density plots contained fewer individuals of $P$. engelmanii and $P$. menzeisii than reference plots, but the fraction of each overstory species compared to all overstory trees remained similar, suggesting that the composition of the litter pool (by species) is also similar between reference and low-density plots. Low-density stands also supported higher percent ground cover of herbaceous vegetation compared to reference plots, which could speed decomposition in this coniferous forest, although the relatively low production of herbaceous biomass may lead to insignificant impacts on nutrient cycling (average 19\% ground cover of herbaceous vegetation in low-density plots). Alternatively, duration of snow cover has not been explored at the CCGSR, but thinning has been shown to cause earlier snowmelt in other highelevation ecosystems (Winkler et al., 2005). Canopy openness in low-density plots may increase soil temperatures, thus speeding decomposition of high phenolic litter, particularly if decreasing stand density leads to earlier snowmelt or warmer microclimates between November and April when maximum air temperatures are below $10{ }^{\circ} \mathrm{C}$.

\section{CONCLUSION}

Mixed coniferous, subalpine forest communities in the Rocky Mountains are historically dense and have experienced infrequent, high-severity fire. However, many subalpine stands are thinned for a number of perceived benefits, including fuel and host reduction for the prevention of wildfire and insect outbreaks. While the ecological outcomes of management are relatively well studied in lower-elevation forests with a history of fire suppression, less is known about the importance 
of stand density on ecological properties of high elevation coniferous forest communities. Nearly two decades after management, stand density significantly influenced the structure and chemistry of subalpine forests in Colorado. Slow growth rates in high-elevation forests may delay canopy closure after forest management, thus leading to long-term alterations in factors associated with canopy openness, including changes in plant community composition and foliar nutrient content. However, overstory density had few effects on ecosystem nutrient cycling, possibly due to counteractive effects on microclimate that enhance decomposition of low quality litter. This retrospective study did not address impacts of current forest management practices; however our data suggest that reductions in overstory density in high-elevation ecosystems may alter long-term ecosystem structure.

Acknowledgements: We are indebted to Tom Thompson, Jennifer Horsman, and Jean Ahrens for their expert assistance with various aspects of field and laboratory analyses reported here. We are also grateful to Dan Binkley for providing valuable comments on an earlier version of this manuscript. We also extend our thanks to Colorado College undergraduates Anne Havemann, Brian Miller, Danica Lombardozzi, and Caitlin O'Brady, for their dedication and enthusiasm in the field. This study was supported in part by the Catamount Center for Geography of the Southern Rockies and by a grant to S.J. Hall from the Andrew W. Mellon Foundation.

\section{REFERENCES}

Aber J.D. and Melillo J.M., 1980. Litter decomposition - measuring relative contributions of organic matter and nitrogen to forest soils. Can. J. Bot./Rev. Can. Bot. 58: 416-421.

Aerts R. and deCaluwe H., 1997. Nutritional and plant-mediated controls on leaf litter decomposition of Carex species. Ecology 78: 244-260.

Apigian K.O., Dahlsten D.L., and Stephens S.L., 2006. Fire and fire surrogate treatment effects on leaf litter arthropods in a western Sierra Nevada mixed-conifer forest. For. Ecol. Manage. 221: 110-122.

Bartos D.L., 2000. Landscape dynamics of aspen and conifer forests. In: Shepperd W.D., Binkley D., Bartos D.L., Stohlgren T.J., Eskew L.G. (Eds.), Sustaining aspen in western landscapes: Symposium Proceedings, Grand Junction, CO, pp. 5-14.

Bormann F.H. and Likens G.E., 1979. Pattern and process in a forested ecosystem, Springer-Verlag, New York.

Boyle S.I., Hart S.C., Kaye J.P., and Waldrop M.P., 2005. Restoration and canopy type influence soil microflora in a ponderosa pine forest. Soil Sci. Soc. Am. J. 69: 1627-1638.

Carpenter A.T., West C.M., and Murray W., 1998. Management plan for the Catamount Ranch Open Space, Teller County, CO, 1998-2002 Teller County Division of Parks, Denver, CO, pp. 1-50.

Chacon P. and Armesto J.J., 2006. Do carbon-based defenses reduce foliar damage? Habitat-related effects on tree seedling performance in a temperate rainforest of Chiloe Island, Chile Oecologia 146: 555565.

Colorado Division of Forestry, 2005. The 2005 Report on the health of Colorado's forests, Colorado Department of Natural Resources, Division of Forestry, Denver, CO, pp. 1-27.

Colorado Forest Restoration Institute, 2006. What's Happening in Colorado's aspen forests? Gradual, long-term changes and recent widespread death of aspen trees. In: Binkley D. (Ed.), Colorado Forest Restoration Institute, Fort Collins, CO, pp. 1-4.

Connaugh C., 1970. Revolt against clearcutting. J. For. 68: 264.
Converse S.J., White G.C., Farris K.L., and Zack S., 2006. Small mammals and forest fuel reduction: national-scale responses to fire and fire surrogates. Ecol. Appl. 16: 1717-1729.

Covelo F. and Gallardo A., 2001. Temporal variation in total leaf phenolics concentration of Quercus robur in forested and harvested stands in northwestern Spain. Can. J. Bot./Rev. Can. Bot. 79: 1262-1269.

Covington W.W., Fule P.Z., Moore M.M., Hart S.C., Kolb T.E., Mast J.N., Sackett S.S., and Wagner M.R., 1997. Restoring ecosystem health in ponderosa pine forests of the Southwest. J. For. 95: 23-29.

Dannenmann M., Gasche R., Ledebuhr A., and Papen H., 2006. Effects of forest management on soil $\mathrm{N}$ cycling in beech forests stocking on calcareous soils. Plant Soil 287: 279-300.

Dannenmann M., Gasche R., and Papen H., 2007. Nitrogen turnover and $\mathrm{N}_{2} \mathrm{O}$ production in the forest floor of beech stands as influenced by forest management. J. Plant Nutr. Soil Sci. 170: 134-144.

Denslow J.S., Ellison A.M., and Sanford R.E., 1998. Treefall gap size effects on above- and below-ground processes in a tropical wet forest. J. Ecol. 86: 597-609.

Feller M.C., Lehmann R., and Olanski P., 2000. Influence of forest harvesting intensity on nutrient leaching through soil in Southwestern British Columbia. J. Sustain. For. 10: 241-247.

Fettig C.J., Klepzig K.D., Billings R.F., Munson A.S., Nebeker T.E., Negron J.F., and Nowak J.T., 2007. The effectiveness of vegetation management practices for prevention and control of bark beetle infestations in coniferous forests of the western and southern United States. For. Ecol. Manage. 238: 24-53.

Forkner R.E. and Marquis R.J., 2004. Uneven-aged and even-aged logging alter foliar phenolics of oak trees remaining in forested habitat matrix. For. Ecol. Manage. 199: 21-37.

Franklin J.F., Spies T., Perry D., Harmon M., and McKee A., 1985. Modifying Douglas-Fir management regimes for nontimber objectives In: Oliver C.D., Hanley D.P., Johnson J.A. (Eds.), Conference on Douglas-fir: stand management for the future, College of Forest Resources, University of Washington, Seattle, WA.

Fuller T.L., Foster D.R., McLachlan T.S., and Drake N., 1998. Impact of human activity on regional forest composition and dynamics in central New England. Ecosystems 1: 76-95.

Ganjegunte G.K., Condron L.M., Clinton P.W., Davis M.R., and Mahieu N., 2004. Decomposition and nutrient release from radiata pine (Pinus radiata) coarse woody debris. For. Ecol. Manage. 187: 197211.

Gilless J.K. and Buongiorno J., 2003. Decision Methods for Forest Resource Management, Academic Press, San Diego, CA.

Grady K.C. and Hart S.C., 2006. Influences of thinning, prescribed burning, and wildfire on soil processes and properties in southwestern ponderosa pine forests: a retrospective study. For. Ecol. Manage. 234: $123-135$.

Griffin P.C. and Mills L.S., 2007. Precommercial thinning reduces snowshoe hare abundance in the short tenn. J. Wildl. Manage. 71: 559564.

Gundale M.J., DeLuca T.H., Fiedler C.E., Ramsey P.W., Harrington M.G., and Gannon J.E., 2005. Restoration treatments in a Montana ponderosa pine forest: effects on soil physical, chemical and biological properties. For. Ecol. Manage. 213: 25-38.

Gundale M.J., Metlen K.L., Fiedler C.E., and DeLuca T.H., 2006. Nitrogen spatial heterogeneity influences diversity following restoration in a Ponderosa Pine Forest, Montana. Ecol. Appl. 16: 479-489.

Gundersen P., Schmidt I.K., and Raulund-Rasmussen K., 2006. Leaching of nitrate from temperate forests - effects of air pollution and forest management. Environ. Rev. 14: 1-57.

Hagar J., Howlin S., and Ganio L., 2004. Short-term response of songbirds to experimental thinning of young Douglas-fir forests in the Oregon Cascades. For. Ecol. Manage. 199: 333-347.

Hart S.C., DeLuca T.H., Newman G.S., MacKenzie M.D., and Boyle S.I., 2005. Post-fire vegetative dynamics as drivers of microbial community structure and function in forest soils. For. Ecol. Manage. 220: $166-184$. 
Hattenschwiler S. and Vitousek P.M., 2000. The role of polyphenols in terrestrial ecosystem nutrient cycling. Trends Ecol. Evol. 15: 238243.

Heckenberger M.J., Kuikuro A., Kuikuro U.T., Russell J.C., Schmidt M., Fausto C., and Franchetto B., 2003. Amazonia 1492: Pristine forest or cultural parkland? Science 301: 1710-1714.

Hessl A., 2002. Aspen, elk, and fire: the effects of human institutions on ecosystem processes. Bioscience 52: 1011-1022.

Hogg E.H., Brandt J.P., and Kochtubajda B., 2005. Factors affecting interannual variation in growth of western Canadian aspen forests during 1951-2000. Can. J. For. Res./Rev. Can. Rech. For. 35: 610-622.

Jennings S.B., Brown N.D., and Sheil D., 1999. Assessing forest canopies and understorey illumination: canopy closure, canopy cover and other measures. Forestry 72: 59-73.

Jonard M., Misson L., and Ponette Q., 2006. Long-term thinning effects on the forest floor and the foliar nutrient status of Norway spruce stands in the Belgian Ardennes. Can. J. For. Res./Rev. Can. Rech. For. 36: 2684-2695.

Jones C.G. and Hartley S.E., 1999. A protein competition model of phenolic allocation. Oikos 86: 27-44.

Kaye J.P. and Hart S.C., 1998. Ecological restoration alters nitrogen transformations in a ponderosa pine-bunchgrass ecosystem. Ecol. Appl. 8: 1052-1060.

Knowles R.D., Pastor J., and Biesboer D.D., 2006. Increased soil nitrogen associated with dinitrogen-fixing, terricolous lichens of the genus Peltigera in northern Minnesota. Oikos 114: 37-48.

Lajzerowicz C.C., Walters M.B., Krasowski M., and Massicotte H.B., 2004. Light and temperature differentially colimit subalpine fir and Engelmann spruce seedling growth in partial-cut subalpine forests. Can. J. For. Res. 34: 249-260.

Lindgren P.M.F., Ransome D.B., Sullivan D.S., and Sullivan T.P., 2006. Plant community attributes 12 to 14 years following precommercial thinning in a young lodgepole pine forest. Can. J. For. Res./Rev. Can. Rech. For. 36: 48-61.

Lindroth R.L. and Hwang S.Y., 1996. Diversity, redundancy, and multiplicity in chemical defense systems of aspen, In: Romeo J.T. Saunders J.A., Barbosa P. (Eds.), Phytochemical diversity and redundancy in ecological interactions, Plenum Press, New York, pp. 25-56.

Lorena C.A., Noe V.D., Victoria C.M., Beatriz B.M., Leticia S.C., and Julia M.M., 2005. Soil nitrogen in relation to quality and decomposability of plant litter in the Patagonian Monte Argentina. Plant Ecol. 181: 139-151.

Maassen S., Fritze H., and Wirth S., 2006. Response of soil microbial biomass, activities, and community structure at a pine stand in northeastern Germany 5 years after thinning. Can. J. For. Res./Rev. Can. Rech. For. 36: 1427-1434.

McCullough D.G., Werner R.A., and Neumann D., 1998. Fire and insects in northern and boreal forest ecosystems of North America. Annu. Rev. Entomol. 43: 107-127.

Moore B.D., Wallis I.R., Wood J.T., and Foley W.J., 2004. Foliar nutrition, site quality, and temperature influence foliar chemistry of tallowwood (Eucalyptus microcorys). Ecol. Monogr. 74: 553-568.

Moran M.D., 2003. Arguments for rejecting the sequential Bonferroni in ecological studies Oikos 100: 403-405.

Müller M.S., McWilliams S.R., Podlesak D., Donaldson J.R., Bothwell H.M., and Lindroth R.L., 2006. Tri-trophic effects of plant defenses: chickadees consume caterpillars based on host leaf chemistry. Oikos 114: 507-517.

National Research Council, 2000. Environmental issues in Pacific northwest forest management, The National Academies Press, Washington DC.
Northup R.R., Dahlgren R.A., and McColl J.G., 1998. Polyphenols as regulators of plant-litter-soil interactions in northern California's pygmy forest: a positive feedback? Biogeochemistry 42: 189-220.

NRCS, 2006. Soil survey of Rocky Mountain National Park, Colorado, National Resources Conservation Service.

Osier T.L. and Lindroth R.L., 2006. Genotype and environment determine allocation to and costs of resistance in quaking aspen Oecologia 148: 293-303.

Petritsch R., Hasenauer H., and Pietsch S.A., 2007. Incorporating forest growth response to thinning within biome-BGC. For. Ecol. Manage. 242: 324-336.

Powers R.F., 1989. Retrospective studies in perspective: strengths and weaknesses. In: Dyck W.J., Mees C.A. (Eds.), Research Strategies for Long-term Site Productivity: Proceedings of the IEA/BE A3 Workshop Seattle, pp. 47-62.

Ranger J., Bonnaud P., Bouriaud O., Gelhaye D., and Picard J.F., 2008. Effects of the clear-cutting of a Douglas-fir (Pseudotsuga menziesii (Mirb.) Franco) plantation on chemical soil fertility. Ann. For. Sci. 65: 303 .

Ripple W.J. and Beschta R.L., 2007. Restoring Yellowstone's aspen with wolves. Biol. Conserv. 138: 514-519.

Schoennagel T., Veblen T.T., and Romme W.H., 2004. The interaction of fire, fuels, and climate across Rocky Mountain forests. Bioscience 54: 661-676.

Sibold J.S., Veblen T.T., and Gonzalez M.E., 2006. Spatial and temporal variation in historic fire regimes in subalpine forests across the Colorado Front Range in Rocky Mountain National Park, Colorado, USA. J. Biogeogr. 33: 631-647.

SPSS, 2005. SPSS 11.0 for Macintosh, SPSS, Inc., Chicago, IL.

Stamp N., 2003. Out of the quagmire of plant defense hypotheses. Q. Rev. Biol. 78: 23-55.

Titus B.D., Prescott C.E., Maynard D.G., Mitchell A.K., Bradley R.L., Feller M.C., Beese W.J.B., Seely B.A., Benton R.A., Senyk J.P., Hawkins B.J., and Koppenaal R., 2006. Post-harvest nitrogen cycling in clearcut and alternative silvicultural systems in a montane forest in coastal British Columbia. For. Chron. 82: 844-859.

Veblen T.T., Kitzberger T., and Donnegan J., 2000. Climatic and human influences on fire regimes in ponderosa pine forests in the Colorado Front Range. Ecol. Appl. 10: 1178-1195.

Vellend M., Verheyen K., Flinn K.M., Jacquemyn H., Kolb A., Van Calster H., Peterken G., Graae B.J., Bellemare J., Honnay O., Brunet J., Wulf M., Gerhardt F., and Hermy M., 2007. Homogenization of forest plant communities and weakening of species-environment relationships via agricultural land use. J. Ecol. 95: 565-573.

Wang J.R., Letchford T., Comeau P.G., and Coopersmith D., 2000. Foliar responses of understorey Abies lasiocarpa to different degrees of release cutting in a Betula papyrifera and conifer mixed species stand. Scand. J. For. Res. 15: 611-620.

Weinig C., Gravuer K.A., Kane N.C., and Schmitt J., 2004. Testing adaptive plasticity to UV: costs and benefits of stem elongation and lightinduced phenolics. Evolution 58: 2645-2656.

Western Regional Climate Center, 2007. Western US climate historical summaries: Ruxton Park, CO.

Winkler R.D., Spittlehouse D.L., and Golding D.L., 2005. Measured differences in snow accumulation and melt among clearcut, juvenile, and mature forests in southern British Columbia. Hydrol. Process. 19: $51-62$.

Zenner E.K., Acker S.A., and Emmingham W.H., 1998. Growth reduction in harvest-age, coniferous forests with residual trees in the western central Cascade Range of Oregon. For. Ecol. Manage. 102: 75-88. 